\title{
CASE REPORT OF A NEONATE WITH CONGENITAL SUPERIOR LUMBAR HERNIA
}

\author{
Stephanus Haryanto Hokardi*, Neil Angelo S. Sael \\ Department of Surgery, De Los Santos Medical Center, 201 E. Rodriguez Sr. Ave., Quezon City, NCR, \\ Philippines.*Correspondence: yanto1886@yahoo.com.
}

\begin{abstract}
Background: congenital lumbar hernias are rare. It constitutes to $20 \%$ of all lumbar hernias which is less than $1.5 \%$ of all the abdominal wall hernias. There are no more than 50 cases reported in literature till date. We report a case of congenital lumbar hernia in a preterm female neonate located on the superior lumbar triangle. Case: a preterm female neonate was born, presented with a mass at the right lumbar area with a size of $8 \times 8 \mathrm{~cm}$, round, movable with bluish discoloration, well delineated border, no visible veins, increases in size when the patient cries, and reduces easily. Ultrasonography revealed a right posterolateral abdominal mass measuring $4.2 \times 2.88 \times 1.59 \mathrm{~cm}$. CT scan revealed right posterolateral mid-abdominal wall hernia with protrusion and no intestinal obstruction. The patient underwent exploratory laparotomy, where hernia defect was about $2 \mathrm{~cm}$ in diameter in the right posterior abdominal wall, pararenal area, and just below the $12^{\text {th }}$ rib. The ascending colon and parts of the ileum were adherent inside the hernia defect at the right lumbar area. Primary closure of the hernia defect was done by suturing the psoas major and the transversus abdominis and internal oblique muscles. The postoperative, patient had good bowel movement, no abdominal distention or vomiting. Feeding was then started and well tolerated. After two weeks follow-up, there were no signs or symptoms of intestinal obstruction such as nausea and vomiting. Patient is being fed regularly and passes bowel movement almost 2-3 times a day. Conclusion: appropriate diagnosis of the extent of the defect through the advent of CT scan and early detection of other congenital anomalies should be routine in these cases. Open surgery with primary repair is almost always done but we can consider laparoscopic approach in the future with uncomplicated lumbar hernias.
\end{abstract}

Keywords: congenital hernia, superior lumbar hernia, surgery.

\section{LAPORAN KASUS NEONATUS DENGAN HERNIA LUMBAR SUPERIOR KONGENITAL}

\author{
Stephanus Haryanto Hokardi*, Neil Angelo S. Sael \\ Departmen Bedah, De Los Santos Medical Center, 201 E. Rodriguez Sr. Ave., Kota Quezon, NCR, Filipina. \\ *Korespondensi: yanto1886@yahoo.com.
}

\begin{abstract}
ABSTRAK
Latar belakang: hernia lumbal kongenital jarang terjadi. Ini merupakan $20 \%$ dari semua hernia lumbar yang mana kurang dari $1,5 \%$ dari semua hernia dinding abdomen. Tidak ada lebih dari 50 kasus yang dilaporkan dalam literatur hingga saat ini. Kami melaporkan kasus hernia lumbar kongenital pada neonatus perempuan prematur yang terletak di segitiga lumbar superior. Kasus: neonatus perempuan prematur lahir, terdapat massa di daerah pinggang kanan dengan ukuran 8x8cm, bulat, dapat digerakkan dengan warna kebiru-biruan, batas baik, tidak ada vena yang terlihat, peningkatan ukuran ketika pasien menangis, dan mengecil dengan mudah. Ultrasonografi menunjukkan massa perut posterolateral kanan berukuran 4,2x2,88x1,59 cm. CT scan menunjukkan hernia dinding abdomen tengah posterolateral kanan dengan protrusi dan tidak ada obstruksi usus.
\end{abstract}


Pasien menjalani laparotomi eksplorasi. Lubang hernia sekitar $2 \mathrm{~cm}$ dan lubang berada di dinding perut posterior kanan, daerah pararenal, dan tepat di bawah tulang rusuk ke-12. Kolon asendens dan bagian ileum melekat di dalam defek hernia di area lumbar kanan. Penutupan primer defek hernia dilakukan dengan menjahitkan psoas major dan transversus abdominis dan otot oblikus internal. Pada pasca operasi, pasien mengalami gerakan usus yang baik, tidak ada distensi abdomen atau muntah. Makan dimulai dan ditoleransi baik. Setelah dua minggu evaluasi, tidak ada tanda-tanda atau gejala obstruksi usus seperti mual dan muntah. Pasien diberi makan secara teratur dan buang air besar 2-3 kali sehari. Simpulan: diagnosis yang tepat mengenai derajat defek melalui CT scan dan deteksi dini anomali kongenital lainnya harus rutin dalam kasus ini. Operasi terbuka dengan perbaikan primer hampir selalu dilakukan tetapi kita dapat mempertimbangkan pendekatan laparoskopi di masa depan dengan hernia lumbar tanpa komplikasi.

Kata kunci: hernia kongenital, hernia lumbar superior, operasi.

\section{INTRODUCTION}

Congenital lumbar hernias are rare abdominal wall hernias in infants and in children. Approximately $10 \%$ are congenital and the majority are unilateral. ${ }^{1}$ They are divided into three types depending on the site. There are superior, which occur through the superior lumbar triangle (Grynfelt-Lesshaft triangle), inferior, which occur through the inferior lumbar triangle (Petit), and combined. Most common location of a congenital lumbar hernia is in the inferior triangle. ${ }^{1,2}$

Less than 50 cases of congenital lumbar hernias are reported in literature till date..$^{2,3,4}$ These hernias may contain colon, small intestine, spleen, or liver and all have been reported. ${ }^{4,5} \mathrm{CT}$ Scan has become the imaging modality of choice in confirming the diagnosis. ${ }^{6}$ Lumbar hernias have a $25 \%$ risk of incarceration and an $8 \%$ risk of strangulation, making surgery a reasonable option for management. ${ }^{5}$

Congenital lumbar hernias when diagnosed, are frequently associated with other anomalies. Lumbocostovertebral syndrome is one example wherein there is a presence of hemivertebra, congenital absence of ribs, anterior mylomeningocele, and hypoplasia of anterior abdominal wall presenting as congenital lumbar hernia. Other anomalies associated are anorectal malformations, hydrocephalus, congenital diaphragmatic hernia, caudal regression syndrome, pelvoureteric junction obstruction, cloacal exstrophy, an absent kidney, or meningomyelocele. Diagnosis of a congenital lumbar hernia must prompt one to investigate further for these anomalies. $^{1,2}$ We report a case of congenital lumbar hernia in a preterm female neonate located on the superior lumbar triangle.

\section{CASE REPORT}

A preterm female neonate was born to a 20-year-old G2P2 (1102) via Cesarean Section at 36 weeks gestation. She presented with a mass at the right lumbar area with a size of $8 \times 8 \mathrm{~cm}$, round, movable with bluish discoloration, well delineated border, no visible veins and increases in size when the patient cries and reduces easily.

Ultrasonography revealed a right posterolateral abdominal mass measuring $4.2 \times 2.88 \times 1.59 \mathrm{~cm}$. A dorsal hernia is considered. There were no signs of bowel obstruction. Mild pelvocaliectasia was noted on the right. The liver, gallbladder, 
pancreas, spleen, left kidney and urinary bladder were unremarkable. There was no hepatobiliary duct ectasia nor demonstrable suprarenal or pelvic mass. The scout film of the abdomen was also done which showed displaced bowel loops in the right lower quadrant.

CT scan (Figure 1a, 1b) revealed minimal to moderate hepatomegaly, normal spleen, multiple surface calcification, sequel of an intrauterine granulomatous infection, right posterolateral mid-abdominal wall hernia with protrusion, no intestinal obstruction, small umbilical hernia. There were no signs of obstruction, no vomiting nor abdominal distention until on the $5^{\text {th }}$ day of life, the patient underwent exploratory laparotomy. Patient was placed in supine position and a transverse incision was made on the abdominal right upper quadrant and carried down to the peritoneum. There was multiple mucoid meconium noted on bowels with minute calcifications. Meconium peritonitis was considered due to the prolonged standing of the congenital lumbar hernia. Bowel run was done and noted no signs of perforation. The bowels were noted to be inflamed in different segments. Adhesiolysis was done with sharp and blunt dissection. Hernia defect was about 2 $\mathrm{cm}$ in diameter and is noted to be in the right posterior abdominal wall, pararenal area, and just below the $12^{\text {th }}$ rib. This marks the superior lumbar triangle. The ascending colon and parts of the ileum were adherent inside the hernia defect at the right lumbar area. Mobilization of the ascending colon and cecum was done then the bowels were delivered from the hernia defect. Primary closure of the hernia defect was done by suturing the psoas major and the transversus abdominis and internal oblique muscles with 6 stitches of Prolene 3-0 simple interrupted suturing. Primary closure was considered due to the presence of meconium peritonitis. Interval appendectomy was done. The rest of the abdominal wall was closed in layers. Patient tolerated the procedure well.

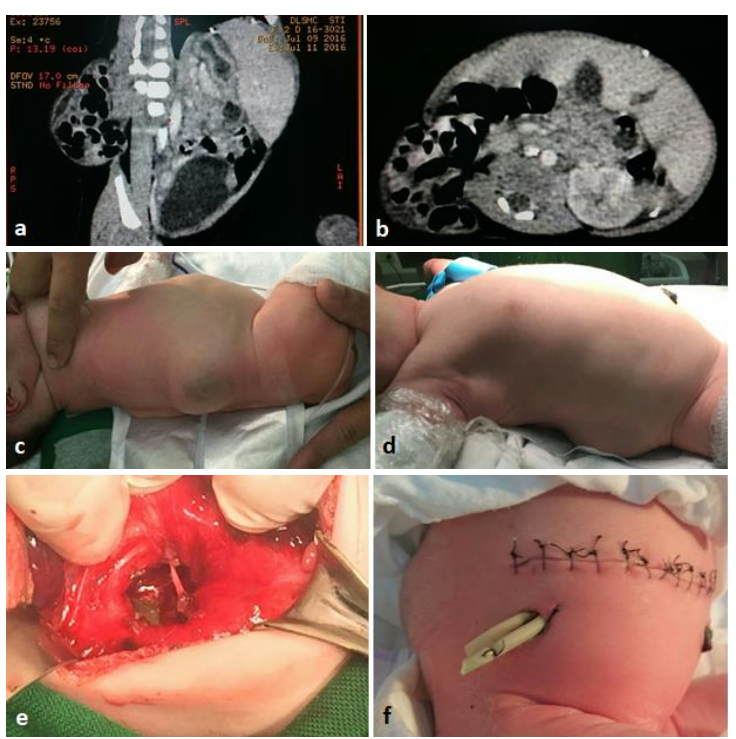

Figure 1. $(a, b) C T$ scan imaging of the right posterolateral abdominal wall hernia. Note only small bowel loops are located in the hernia defect; (c,d) pre-operative images of the congenital lumbar hernia; (e) intraoperative image of the hernia defect; (f) post-operative image.

The immediate postoperative period was uneventful. On the second postoperative day, patient had 3 episodes of bowel movement. No abdominal distention or vomiting was noted. Repeat scout film of the abdomen was done which revealed non-dilated bowel loops in the abdominal cavity. No free air noted. Feeding was then started and well tolerated. The rest of the hospital stay was unremarkable. Antibiotics were completed and on the $16^{\text {th }}$ day of life, baby was sent home with stable vital signs, good suck, and active.

After two weeks follow-up, there were no signs or symptoms of intestinal 
obstruction such as nausea and vomiting. Patient is being fed regularly and passes bowel movement almost 2-3 times a day.

\section{DISCUSSION}

The most common site of congenital lumbar hernias is found in the inferior lumbar triangle or Petit triangle. ${ }^{7}$ Acquired or traumatic lumbar hernias are more frequently seen in the superior lumbar triangle because it is the thinnest area in the lateral and posterior abdominal wall. Hernias from this location result from direct trauma, flank incision, or an abscess. ${ }^{5}$ In our case, the patient presented with a congenital lumbar hernia at the superior lumbar triangle which is rare. ${ }^{8}$ During embryologic development, weakening of the area of the aponeuroses of the layered abdominal muscles that derive from somatic mesoderm, which invades the somatopleure, may potentially lead to lumbar hernias. ${ }^{5}$

The aim of the surgery is to reduce the hernia sac, repair the defect and to strengthen the weakened posterior abdominal wall. It could be done by simple anatomical closure, overlapping of the aponeurosis, or use of prosthetic meshes or laparoscopic mesh repair in cases of uncomplicated lumbar hernias. ${ }^{3,6}$

Elective surgical repair is suggested at any early age to prevent incarceration and strangulation. ${ }^{9}$ Intervention should be done before 12 months because the hernia defect may enlarge with growth making primary direct closure with surrounding tissue difficult. ${ }^{9}$ Because of the rarity of congenital lumbar hernia, appropriate surgical procedures are still controversial. Open repair has been performed in most patients. ${ }^{1,2,5,10}$ and laparoscopic repair is preserved with small uncomplicated hernias. In the present case, the hernial defect was large, and surrounding abdominal wall muscles were hypoplastic. Primary closure was also intended due to the presence of meconium peritonitis and mesh repair was not considered.

Aside from primary closure, muscle grafts could be done by using a fascia lata graft. ${ }^{9}$ Currently, laparoscopy is also being performed in patients with congenital lumbar hernia. It could be approached either transabdominally or extraperitoneally and minimal reports of recurrence is seen. $2,5,6,9,11$

\section{CONCLUSION}

Congenital lumbar hernia is one of the rare types of hernias reported in neonates; and occasionally in older children. Appropriate diagnosis of the extent of the defect through the advent of CT scan and early detection of other congenital anomalies should be routine in these cases. Since there is almost to none regarding Philippine literature on the practice of congenital lumbar hernia, we can recommend further studies for the surgical approaches in this anomaly. Open surgery with primary repair is almost always done but we can consider laparoscopic approach in the future with uncomplicated lumbar hernias.

\section{REFERENCES}

1. Al-Salem AH. Abdominal Wall Hernias and Hydroceles. In: Al-Salem AH, editor. An Illustrated Guide to Pediatric Surgery. Switzerland: Springer; 2014. p.15-27.

2. Esposito C, Settimi A, De Marco M, et al. Congenital Lumbar Hernia: Two Case Reports and a Review of the Literature. Journal of Pediatric Surgical Specialties. 2009;3:40-2. 
3. Wakhlu A, Wakhlu AK. Congenital lumbar hernia. Pediatr Surg Int. 2000;16:146-8.

4. Peláez Mata DJ, Alvarez Munoz V, Fernandez Jimenez I, et al. Congenital lumbar hernia. Cir Pediatr. 1998;11:126-8.

5. Stamatiou D, Skandalakis JE, Skandalakis LJ, et al. Lumbar hernia: surgical anatomy, embryology, and technique of repair. $\mathrm{Am}$ Surg. 2009;75:202-7.

6. Dakin GF, Kendrick ML. Challenging Hernia Locations: Flank Hernias. In: Jacob BP, Ramshaw B, editors. The SAGES Manual of Hernia Repair. New York: Springer; 2013. p. 531-40.

7. Pachani AB, et al. A Primary Idiopathic Superior Lumbar Triangle Hernia with Congenital Right Scoliosis: A Rare Clinical Presentation and Management. Int J Appl Basic Med Res. 2011;1:60-2.

8. Tavares-de la Paz LA, Martínez-Ordaz JL. Lumbar hernia. Case report and literature review. Cir Cir. 2007;75:3814.

9. Morita K, Miyano G, Nouso H, et al. Laparoscopic repair for a congenital lumbar hernia with free fascia lata graft reinforcement. J Pediatr Surg Case Rep. 2014;2:101-3.

10. Sharma A, Pandey A, Rawat J, et al. Congenital lumbar hernia: 20 years' single centre experience. J Paediatr Child Health. 2012;48:1001-3.

11. Moreno-Egea A, Baena EG, Calle MC, et al. Controversies in the Current Management of Lumbar Hernias. Arch Surg. 2007:142:82-8. 